\title{
VIOLÊNCIA ESCOLAR: na escola, da escola e contra a escola
}

\author{
L a violence écolière: \\ dans l'école, par l'école et contre l'école
}

\begin{abstract}
Elis Palma Priotto ${ }^{a}$ Lindomar Wessler Boneti ${ }^{b}$
a Mestre em Educação, Enfermeira, D ocente curso de Enfermagem da Universidade Estadual do Oeste do Paraná (Unioeste), Paraná - Brasil, e-mail: elispalmapriotto@ hotmail.com

${ }^{\mathrm{b}}$ D outor (Ph.D ) em Sociologia, Professor do Programa de Pós-G raduação em Educação da Pontifícia Universidade Católica do Paraná (PUCPR), Curitiba, PR - Brasil, e-mail: boneti.lindomar@pucpr.br
\end{abstract}

\section{Resumo}

0 texto busca construir uma definição mais ampla de violência escolar em relação as que normalmente se apresentam nos referenciais bibliográficos sobre o tema. Esta ampliação da definição referida se embasa na compreensão do fenômeno como algo intrinsecamente relacionado ao contexto social, cultural e histórico em que ele se dá. Este artigo analisa a maneira de como abordar a questão violência escolar diante das manifestações que ocorrem dentro das instituições escolares e que estão relacionadas tanto a problemas internos como externos do cotidiano escolar. Assim distingue-se violência na escola, violência da escola e violência contra a escola. A análise construída neste texto tem como base dados coletados em duas pesquisas, a primeira, realizada em 2006, intitulada "Características da violência escolar envolvendo adolescentes"; a segunda, realizada nos anos de 2007 e 2008, com o objetivo da realização da dissertação de mestrado, intitulada "Violência escolar: Políticas Públicas e Práticas educativas".

Palavras-chave: Violência escolar. Violência da escola. Violência na escola. Violência contra a escola.

Rev. D iálogo Educ., Curitiba, v. 9, n. 26, p. 161-179, jan./ abr. 2009 


\section{Resumé}

Le texte a le bout construit une définition plus ample de la violence écolière en rapport celles qui normalement sont mentionnés dans les références bibliographiques sur le thème. Cette ampliation de la définition de la thématique mentionnée s'étaye sur la conception du phénomène en tant que quelque chose intrinsèquement rapporté au contexte social, culturel et historique dans lequel ce phénomène se réalise. Ce texte analyse les différents façons de traiter la violence écolière en considérant que l'origine de ce problème n'est pas uniquement dans l'école mais aussi en dehors du contexte écolier. Ainsi, il faut distinguer la violence dans l'école, la violence par l'école et la violence contre l'école

Mots-clés: Violence écolière. Violence dans l'école. Violence par l'école. Violence contre l'ecole.

Considera-se bastanteamplo o próprio conceito de violência, fenômeno esse presente em todas as sociedades. É um fenômeno inerente à vida humana que permeia historicamente a vida social e só pode ser explicado a partir de determinações culturais, políticas, econômicas e psicossociais, intrínsecas às sociedades humanas.

As características e formas de apresentação de violência são: violência doméstica, política, policial, religiosa, criminal, simbólica, nas ruas, no trânsito, nas escolas, no campo, contra o jovem, a criança, a mulher, o idoso, o portador de necessidades especiais, o afro-descendente, o homossexual, entre outras.

Isto é, genericamente a violência pode ser entendida como uma ação diretamente associada a uma pessoa ou a um grupo, a qual interfere na integridade física, moral ou cultural de uma pessoa ou de um grupo, mas também esses efeitos podem ser provocados por acontecimentos e/ ou mudanças radicais ocorridas na sociedade atingindo negativamente os indivíduos ou a coletividade em relação aos laços de pertencimentos, dos meios e condições de vida, etc.

Sabe-se que não é fato novo a preocupação de membros eautoridades com a violência escolar, que diariamente a sociedade enfrenta. E sse problema centrase nas proporções inéditas que o fenômeno vem assumindo e se transformam em preocupação e insegurança, aos diretores, alunos, professores, pais e sociedade.

D enomina-se violência escolar todos os atos ou ações de violência, comportamentos agressivos e antissociais, incluindo conflitos interpessoais, danos ao patrimônio, atos criminosos, marginalizações, discriminações, dentre outros

Rev. Diálogo Educ., Curitiba, v. 9, n. 26, p. 161-179, jan./ abr. 2009 
praticados por, e entre, a comunidade escolar (alunos, professores, funcionários, familiares e estranhos à escola) no ambiente escolar.

Considerando o exposto, neste texto busca-se analisar a violência escolar, como ela se apresenta especialmente na perspectiva de distinguir o que é violência na escola, da escola e contra a escola.

A análise realizada neste texto tem como base uma pesquisa realizada objetivando a elaboração da dissertação de mestrado intitulada "Violência escolar: Políticas públicas e práticas educativas" (PRIOTTO, 2008, p. 200). A referida pesquisa tinha como objetivo identificar nas políticas públicas a relação com a temática violência e quais as práticas educativas efetivadas pelas escolas públicas para prevenir a violência escolar. 0 presente estudo utilizou também outra pesquisa, realizada pela mesma autora, em 2006, que tinha como objetivo estudar as características da violência escolar envolvendo adolescentes.

\section{0 que é e como se expressa a violência escolar}

Ao se pesquisar sobre estudos realizados e publicados sobre aviolência escolar na perspectiva de favorecer a compreensão em relação ao tema, verificou-se que as produções sobre essas temáticas versam sobre diferentes aspectos, delimitandose, especialmente, à sociedade contemporânea. Existem estudos que consideram a violência escolar analisando-a a partir de questões geográficas, como é o caso de situações semelhantes às vivenciadas hoje, como escolas próximas de favelas com 0 predomínio do tráfico de drogas e do crime organizado. Outros situam a questão à fase da adolescência e às questões comportamentais dos alunos nesta faixa de idade, ressaltando-se as agressões. O utros ainda associam os pequenos delitos, como furtos dentro da escola, às características das incivilidades e do processo de crescimento econômico e social. Com isso, percebe-se a preocupação de professores e diretores, preocupados com as possíveis invasões e depredações ao patrimônio público, na busca de uma gestão mais democrática com a participação de pais e alunos para amenizar os possíveis conflitos existentes.

Colombier (1989), no livro "Violência na escola", retrata a opinião normalmente exposta pelo corpo docente da escola. O u seja, trata-se de entender o fenômeno da violência nas escolas como atos de violência contra as instalações da escola, contra os professores e dos alunos uns contra os outros, apontando os fundamentos socioeconômicos e familiares como causa, numa tentativa de apontar possíveis soluções para o problema.

Spósito (2002) analisou um conjunto de estudos sobre violência escolar onde citou que muitas das ocorrências acontecem em várias cidades do país, não sendo restritas às grandes cidades e capitais. 0 autor ressalta que no

Rev. D iálogo Educ., Curitiba, v. 9, n. 26, p. 161-179, jan./ abr. 2009 
período de 1990 a 1999 as pesquisas intensificaram-se sobre questões do comportamento dos jovens especialmente no que se refere a vandalismos e agressividade contra o professor.

Ainda de acordo com Spósito, no período de 2000, 2002 e 2003, o fenômeno estava presente tanto nas escolas de caráter disciplinar rígido quanto em escolas permissivas e desorganizadas. Constatou que houve a busca de policiamento no entorno da escola e dentro da escola em alguns momentos, no intuito de diminuir as depredações e conflitos. $\mathrm{O}$ autor cita que as brigas físicas, violência contra a pessoa, aumentaram entre os alunos, nesse período, e que já se procurava associar a questão às políticas sociais.

As pesquisas também mostram a diversidade de temas procurando compreender 0 aluno adolescente, como vítima e/ ou agressor da violência escolar, inserido numa sociedade, como sendo estigmatizado, excluído. Ou seja, que a violência escolar não é exclusivamente escolar, pois exprime uma espécie de afirmação, pela violência, do direito a ser reconhecido, em situações de extrema desvantagem, decorrentes do estigma.

Laterman (2000; SPÓ SITO 2002, p. 151) chama a atenção para a questão da relação entre aluno e professor e refere que "não é possível afirmar que as incivilidades se somam ou se transformam, ao longo do tempo, em crimes, como se fossem uma gênese daqueles acontecimentos mais graves". No entanto, a autora destaca o fato de que os limites antissociais das condutas, sendo ultrapassados, facilitaram esse indesejável avanço, o que representa a ausência de poder dos pais, da sociedade em geral ou a ausência dos próprios valores.

Pereira (2003), em sua pesquisa intitulada "Violência nas Escolas: visão de Professores do Ensino Fundamental sobre esta questão", analisa as formas como isto ocorre e as estratégias que são utilizadas para sua superação. Esta autora constatou que os professores percebem as violências como um fenômeno em expansão, reforçado, principalmente pelas desigualdades sociais, pela influência da mídia e pela desestruturação familiar, impondo consequências no cotidiano escolar.

Outros estudos levam em conta o cotidiano da escola para identificar os tipos de violência ali gerada. É o que mostra o estudo de Priotto (2006), enfocando as características da violência escolar no cotidiano de duas escolas, uma pública e uma particular, no município de Foz do Iguaçu, Paraná. Essa pesquisa teve como objetivo identificar os tipos de violência sofrida no âmbito escolar, como os professores e alunos identificam a violência gerada e qual a relação desta com a fase da adolescência. 0 estudo conclui que o tipo de violência gerado na escola pública e particular tem as mesmas características, porém os professores da escola pública e da escola particular têm concepções diferentes a respeito do papel da escola em relação ao quadro geral de violência e de como lidar com os alunos adolescentes destas.

Rev. Diálogo Educ., Curitiba, v. 9, n. 26, p. 161-179, jan./ abr. 2009 
Cabe salientar que muitos dos trabalhos que analisam a temática sobre a violência escolar, se referem a esse tipo de violência como consequência de um processo que começaria na família, a desestruturação familiar, a falta de limites e de referências da maioria dos adolescentes e teria continuidade nos grupos e relações sociais pertencentes ao ambiente externo à escola. A parecem também, nos estudos realizados sobre a violência escolar, as causas socioeconômicas, a exclusão social, ou melhor, a falta de acesso, o tráfico de drogas, a falta de oportunidades e de trabalho, a influência da mídia, o rápido crescimento biológico, o tempo livre e ocioso, a falta de perspectivas, falta de um sonho. Todos considerados fatores causadores da violência escolar.

Assim, considera-se como violência escolar todos os fatos, como é o caso dos atos de agressões, que ocorrem no sistema escolar, entendendo como sistema e espaço físico, local onde se acentuam os problemas individuais. Este entendimento é diferente de Furlong $(2005$, p. 4) que refere como violência esolar como sendo escola, como sistema, que causa ou acentua os problemas individuais.

De fato, o caráter multifacetado da violência no ambiente escolar impõe uma série de desafios no que tange à definição do fenômeno. Um desses é distinguir o fenômeno violência escolar para que se possa estabelecer com clareza o papel dos educadores e da escola enquanto instituição na prevenção da violência.

Neste sentido, para que se possa compreender melhor a descrição de violência escolar, optou-se apresentar a descrição de violência na escola por Abramovay (2003), seguido da classificação de violência na escola em três níveis, identificados por Charlot (1997 apud ABRAMOVAY, 2003, p. 95). A partir desta classificação dos episódios de violência na escola elaborada por Charlot (2002) e comentada por Abramovay (2005), elaborou-se uma classificação própria apresentada numa das pesquisas em análise neste texto (PRIOTTO 2008).

Abramovay (2003) classifica o fenômeno como violência na escola, e a pesquisadora Priotto (2008) refere como violência esolar, considerando que esta denominação é mais abrangente por englobar violência na, da e œntra a escola. Sendo que a violência escolar para Priotto (2008) e a violência na escola para Abramovay (2003) pode se expressar através dos seguintes eventos:

a) violência Física: de um indivíduo ou grupo contra a integridade de outro(s) ou de grupo(s) e também contra si mesmo, abrangendo desde os suicídios, espancamentos de vários tipos, roubos, assaltos e homicídios. Além das diversas formas de agressões sexuais;

b) agressão Física: homicídios, estupros, ferimentos, roubos, porte de armas que ferem, sangram e matam.

c) violência Simbólica: Verbal - abuso do poder, baseado no consentimento que se estabelece e se impõe mediante o uso de

Rev. D iálogo Educ., Curitiba, v. 9, n. 26, p. 161-179, jan./ abr. 2009 
símbolos de autoridade; Institucional - marginalização, discriminação e práticas de assujeitamento utilizadas por instituições diversas que instrumentalizam estratégias de poder;

d) violência Verbal: incivilidades (pressão psicológica), humilhações, palavras grosseiras, desrespeito, intimidação ou "bullying".

O bullying, considerado como um ato de violência, devido aos comportamentos apresentados, tem origem na palavra inglesabully, ou seja, valentão. Isto ocorre "quando alguém faz ou diz coisas para mostrar poder sobre outra pessoa" Para os autores, os resultados dessa violência podem causar "desinteresse pelos estudos, depressão ou até reações extremamente violentas". (AMO RIM; RO MANELLI, 2005, p. 65 apud WHAT, 2003).

Observa-se que atitudes como ofender, ignorar, excluir, ferir, humilhar, sempre foram encontradas nas escolas, não importando se de ensino público ou particular, se de ensino fundamental ou médio. 0 fenômeno tem-se estendido cada vez mais para as séries iniciais e acaba muitas vezes por sair da escola e invadir a vida pessoal, através de mensagens pela Internet e celulares.

A partir dessas características de violência escolar expressas acima, os autores Charlot (1997) e Abramovay (2003) classificaram os atos e as ações de violência na escola em dois níveis: a incivilidades, a violência simbólica ou institucional:

[...] este classificou a violência na escola em três níveis: a violência- golpes, deferimentos, violência sexual, roubos, crimes, vandalismo; a incivilidades- humilhações, palavras grosseiras, falta de respeito; a violência simbólica ou institucional - falta de sentido em permanecer na escola por tantos anos; o ensino como um desprazer que obriga o jovem a prender matérias e conteúdos alheios aos seus interesses; as imposições de uma sociedade que não sabe acolher os seus jovens no mercado de trabalho; a violência das relações de poder entre professores e alunos; a negação da identidade e satisfação profissional aos professores, a sua obrigação de suportar o absentismo e a indiferença dos alunos. (CHARLOT, 1997 apud ABRAMOVAY, 2003, p. 95).

Em 2002, novamente Charlot (2002) propõe um sistema de classificação dos episódios de violência na escola na qual identificam três tipos de manifestação como: violência na escola, violência da escola, violência contra a escola.

Rev. Diálogo Educ., Curitiba, v. 9, n. 26, p. 161-179, jan./ abr. 2009 
Violência na escolaé aquela que se produz dentro do espaço escolar, sem estar ligada à natureza e as atividade da instituição escolar: quando um bando entra na escola para acertar contas das disputas que são as do bairro, a escola é apenas o lugar de umaviolência que teria podido acontecer em qualquer outro local. Violência da escola esta ligada à natureza e às atividades da instituição escolar: quando os alunos provocam incêndios, batem nos professores ou os insultam, eles se entregam aviolência que visam diretamente à instituição e aqueles que a representam. Essa violência contra a escola deve ser analisada com a violência da escola: uma violência institucional, simbólica, que os próprios jovens suportam através da maneira como a instituição e seus agentes os tratam (modos de composição das classes, de atribuição de notas, de orientação, palavras desdenhosas dos adultos, atos considerados pelos alunos como injustos ou racistas). (CHARLOT, 2002, p. 434).

No entanto, para Abramovay (2005) essa classificação mostra-se insuficiente para certos tipos de manifestações de violências existentes na escola como: brigas entre alunos ou as discussões entre professores e alunos que se dão na sala de aula ou no pátio da escola.

Essa proposta de classificação da violência nas escolas ajuda a compreender o fenômeno na medida em que considera manifestações de várias ordens. Contudo, mostra-se insuficiente para compreender certos tipos de manifestações que ocorrem dentro dos estabelecimentos de ensino e que estão relacionadas a problemas internos de funcionamento, de organização e de relacionamento. (ABRAMOVAY, 2005, p. 77).

Por outro lado, esse olhar sobre a violência escolar consiste em um ganho na medida em que possibilita a defesa por um conceito de violência fundamentado num contexto social, histórico, cultural em que ele se dá com vantagens de poder envolver ações, comportamentos e situações diferenciadas que envolvem indivíduos distintos (professores, alunos, membros da comunidade e demais membros da comunidade escolar).

Abramovay (2005, p. 79) afirma que:

Assim, não são apenas os episódios graves e espetaculares - como homicídios, porte e uso de armas - que são

Rev. D iálogo Educ., Curitiba, v. 9, n. 26, p. 161-179, jan./ abr. 2009 
compreendidos como violência, mas também conflitos, comportamentos e práticas institucionais incorporadas ao cotidiano dos estabelecimentos de ensino.

Portanto a violência escolar pode ser entendida como uma construção social, que se dá em meio a interações entre sujeitos no espaço escolar. Enfatizando a probabilidade da violência como um processo social que compreende tanto relações externas como internas, e institucionais, em particular no que tange às relações sociais entre sujeitos diversos.

\section{Violência na escola, da escola e contra a escola}

Priotto (2008) com base no estudo realizado na perspectiva da elaboração da dissertação de mestrado intitulada "Violência escolar: Políticas públicas e práticas educativas" ampliou a classificação de violência escolar apresentadas por Charlot (2002) e Abramovay (2005) de forma a ficar um pouco mais abrangente, propondo uma diferenciação entre violência na escola, violência contra a escola, e violência da escola.

No que diz respeito à violência na escola, esta se caracteriza por diversas manifestações que acontecem no cotidiano da escola, praticadas por e entre professores, alunos, diretores, funcionários, familiares, ex-alunos, pessoas da comunidade e estranhos. Caracterizam-se como atos ou ações de violência: Física - contra o(s) outro(s) ou contra o grupo, contra si próprio (suicídios, homicídios, espancamentos, deferimentos, roubos, assaltos, ferimentos, golpes, estupro, agressões sexuais, exibicionismo, porte de armas que ferem, sangram e matam; drogas [uso, oferta, venda, distribuição de Álcool, Tabaco, Maconha, Cocaína, Crack, Merla, Anfetamínicos e outros]). Incivilidades - desacato, palavras grosseiras, indelicadeza, humilhações, falta de respeito, intimidação ou bullying. Como reforça Fukui (1991), essas ações costumam ocorrer: dentro da escola (pátio, quadra, salas de aula); portão de entrada da escola e na via pública em frente à escola. Com efeito, esses atos de violência sempre envolvem indivíduos pertencentes à escola, como vítimas ou como agressores.

Violência ontra a escola é representada como atos de vandalismo, incêndios e destruição, roubo ou furtos do patrimônio como: paredes, carteiras, cadeiras, portas, cabos de fiação, cabos de telefone, materiais e equipamentos das instituições escolares. Esses atos de violência implicam tanto aos membros da escola como à comunidade e estranhos à escola.

Em relação à violência da escola, mostra-se todo tipo de práticas utilizadas pela instituição escolar que prejudicam seus membros (qualquer um destes) como: os fracassos escolares, falta de interesse em permanecer na escola,

Rev. Diálogo Educ., Curitiba, v. 9, n. 26, p. 161-179, jan./ abr. 2009 
o conteúdo alheio aos interesses dos alunos e do mercado de trabalho, os preconceitos (racismo), a desvalorização (tanto da instituição para com o aluno, como do aluno para si mesmo). A indisciplina, a expulsão, a intimidação, 0 ameaçar - abuso do poder (baseado no consentimento que se estabelece e se impõe mediante o uso de símbolos de autoridade por parte dos professores, diretores e supervisores, exemplo: avaliação, atribuição de notas, entrega do boletim, a marginalização, a desvalorização do profissional professor, a insatisfação, indiferença, absentismo dos alunos, despreparo do profissional, falta de estímulos e interesse em educação continuada, discriminações diárias onde se destacam como violentas situações que não envolvem a força, mas se caracterizam por ações de força, como as que Abramovay (2003, p. 98) afirma ser violência "magoar, agredir por falta de respeito" que para os jovens são atos de violência por parte dos professores.

A violência na escola em alguns casos deve ser analisada como a violência da escola: aluno agredir ou usar de forças ou não contra o professor, diretor ou funcionário. Caracteriza-se uma violência aquela gerada pela instituição escolar e seus agentes os através do trato a partir de regras e normas estabelecidas. Ilustram esse tipo de situação as falas do pessoal da escola entrevistado por Priotto (2008, p. 92):

Q ualquer coisinha eles estão chamando os pais qualquer coisinha olha... É injusto... Parece que elas querem irritar a gente pra elas poderem dar motivo pra elas chamar nossos pais parece que elas.... Não vou dizer ferrar a gente, parece que elas querem sabe...

As guerras aqui na escola ta mais... Aqui na entrega de boletim... Principalmente as guerras mais... Um exemplo as mesas estão tudo ali organizada e nóis vamos junto com os pais (eles pedem pra gente vir junto, não sei pra quê) e de repente os professor pede licença que - eu quero falar com os pais de vocês. Fala com os pais da gente e mete a faca, falando mal da gente e a gente não pode falar nada... Se defender...

Cabe salientarmos que, dentro do conceito de violência escolar existe certa confusão entre os termos violência e indisciplina, até porque muitas vezes esses termos são utilizados como sinônimos no cotidiano escolar.

Assim são necessárias algumas breves considerações acerca da indisciplina. Tal como a violência à indisciplina constitui-se um desafio para a escola na atualidade.

Rev. D iálogo Educ., Curitiba, v. 9, n. 26, p. 161-179, jan./ abr. 2009 
Autores como D ebarbieux (2001) e Caldeira (2001) conceituam indisciplina como quebra de regras estabelecidas para um determinado ambiente, local, causando incômodos e perturbando seu funcionamento e que no conceito de indisciplina existe uma causa que prejudica o funcionamento do ambiente e não necessariamente ao outro ser humano.

Indisciplina pode ser entendida como uma forma de manifestação contra a exigência ou quebra de regras ao adequar-se à sociedade. É como o autor Camacho (2001, p. 129) refere "[...] como resistência, ousadia e inconformismo".

Nesta concepção, quebra de regras pode significar prejuízo ou danos apenas aparentemente e não necessariamente um rompimento do trabalho pedagógico. Surgem "falas, movimento, rebeldia, oposição, inquietação, busca de respostas por parte dos alunos e dos professores..." . Q uando surge a indisciplina é importante analisar os motivos desta e adequar-se a mudanças para melhorar a qualidade do processo educativo.

Neste entendimento, violência difere-se por causar danos e/ ou sofrimento ao outro ou a algo que lhe pertence. Assim quando a indisciplina não é entendida pelo professor, a escola pratica violência da escola.

O utra problemática classificada como violência da escola é a da exclusão social causada pela evasão escolar. No Brasil, os processos de exclusão tornaram-se ainda mais graves, pois o conceito de cidadania no país apresenta uma perspectiva diferenciada das sociedades individualistas modernas. A produção da exclusão no âmbito da sociedade é, também, praticada no âmbito da educação.

Coincidentemente, os mesmos cidadãos que são excluídos do direito à habitação, ao emprego, à saúde etc., são também excluídos do direito à educação. As desigualdades presentes no campo social apresentam-se na escola sob a forma de reprovações, sucessão e abandonos e retornos e, por fim, a exclusão definitiva. Está formado, assim, o ciclo das desigualdades: baixa escolaridade, falta de qualificação profissional, falta de emprego. Tornando-os vulneráveis socialmente.

No que tange às desigualdades no âmbito educacional, podemos afirmar que a repetência e 0 abandono de crianças e jovens da escola "é o produto do funcionamento do aparelho escolar" (AD O RNO, 1994, p. 22), mediada pelas desigualdades econômicas e sociais, bem como por fatores culturais e políticos. Assim, a violência interna e circundante à escola, frequentemente atribuída aos jovens excluídos (ou em vias de exclusão) da escola é também o produto do funcionamento de uma sociedade construída com base nestas desigualdades.

Na sequência, apresenta-se a Tabela 1 com os dados trazidos por Priotto (2008, p. 97-103) para melhor exemplificar atos ou ações de violência escolar, na classificação de: violência na escola, violência contra a escola, e violência da escola, baseando-se nos critérios de classificação de Charlot $(1997,2002)$ e Abramovay (2003, 2005).

Rev. Diálogo Educ., Curitiba, v. 9, n. 26, p. 161-179, jan./ abr. 2009 
TABELA 1 - Violência escolar: na escola, da escola, contra escola

\begin{tabular}{|c|c|c|}
\hline $\begin{array}{l}\text { Descrição da } \\
\text { Violência escolar } \\
\text { por Charlot (1997) } \\
\text { e Abramovay (2003) }\end{array}$ & $\begin{array}{l}\text { Narração de fatos ocorridos nas } \\
\text { escolas pesquisadas }\end{array}$ & $\begin{array}{l}\text { Classificação sugerida } \\
\text { por Priotto (2008) } \\
\text { para identificação de } \\
\text { violência escolar } \\
\text { seguindo descrição } \\
\text { dos autores Charlot } \\
\text { e Abramovay }\end{array}$ \\
\hline $\begin{array}{l}\text { a) Violência física: } \\
\text { D e um indivíduo ou grupo } \\
\text { contra a integridade de } \\
\text { outro(s) ou de grupo(s) e } \\
\text { também contra si mesmo, } \\
\text { abrangendo desde os } \\
\text { suicídios, espancamentos de } \\
\text { vários tipos, roubos, assaltos } \\
\text { e homicídios, agressões } \\
\text { sexuais. Incluímos aqui, o } \\
\text { uso de drogas como causas } \\
\text { de danos a si mesmo; }\end{array}$ & 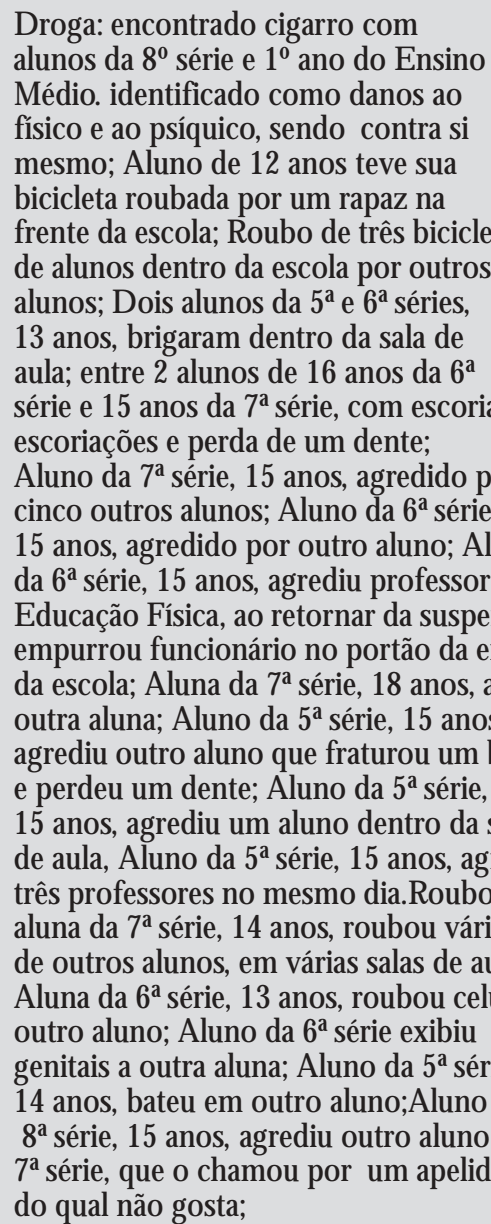 & $\begin{array}{l}\text { Violência na escola } \\
\text { etas } \\
\text { s } \\
\text { lações } \\
\text { oor } \\
\text { e, } \\
\text { luno } \\
\text { r de } \\
\text { ensão, } \\
\text { entrada } \\
\text { agrediu } \\
\text { S, } \\
\text { braço } \\
\text { sala } \\
\text { rediu } \\
\text { / Furto: } \\
\text { ios objetos } \\
\text { ula; } \\
\text { lular de } \\
\text { rie, } \\
\text { da } \\
\text { da } \\
\text { lo } \\
\end{array}$ \\
\hline
\end{tabular}

Rev. D iálogo Educ., Curitiba, v. 9, n. 26, p. 161-179, jan./ abr. 2009 


\begin{tabular}{|c|c|c|}
\hline $\begin{array}{l}\text { b)Agressão física: } \\
\text { homicídios, estupros, } \\
\text { ferimentos, roubos, } \\
\text { porte de armas que ferem, } \\
\text { sangram e matam. }\end{array}$ & 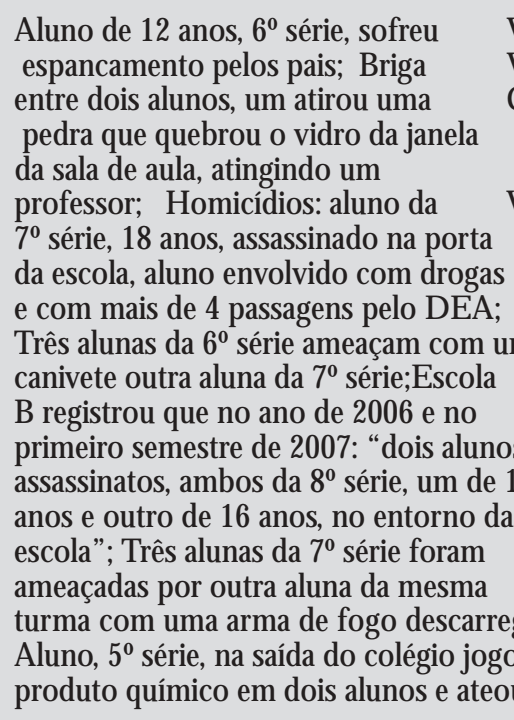 & $\begin{array}{l}\text { Violência na escola } \\
\text { Violência na escola e } \\
\text { Contra a escola } \\
\text { Violência na escola } \\
\text { um } \\
\text { os } \\
\text { a } \\
\text { egada; } \\
\text { ou } \\
\text { ou fogo; }\end{array}$ \\
\hline $\begin{array}{l}\text { c) Violência simbólica - } \\
\text { Verbal: Abuso do poder, } \\
\text { baseado no consentimento } \\
\text { que se estabelece e se impõe } \\
\text { mediante o uso de símbolos } \\
\text { de autoridades; }\end{array}$ & $\begin{array}{l}\text { Dois alunos saíram da sala de aula e, } \\
\text { dirigindo-se ao banheiro, foram } \\
\text { abordados por um policial que fazia } \\
\text { uma palestra na escola, um dos alunos } \\
\text { desacatou o policial; Mãe pediu } \\
\text { ajuda da coordenação pedagógica } \\
\text { para que o professor de Educacaão } \\
\text { Física devolvesse a corrente de ouro } \\
\text { de sua filha que o mesmo pegou, } \\
\text { perguntado ao professor, este alegou } \\
\text { que perdeu a corrente...; }\end{array}$ & $\begin{array}{l}\text { Violência na escola } \\
\text { Violência da escola } \\
\text { pelo uso de poder e, } \\
\text { caso a escola não } \\
\text { tenha feito nada é } \\
\text { violência na escola } \\
\text { por caracterizar } \\
\text { roubo. }\end{array}$ \\
\hline $\begin{array}{l}\text { c.1) Violência simbólica - } \\
\text { Institucional: } \\
\text { marginalização, discriminação } \\
\text { e práticas de assujeitamento } \\
\text { utilizadas por instituições } \\
\text { diversas que instrumentalizam } \\
\text { estratégias de poder. }\end{array}$ & $\begin{array}{l}\text { Assinatura em Branco: Em alguns } \\
\text { casos de transferência de alunos } \\
\text { de outras escolas a direção somente } \\
\text { aceita este(s) mediante assinatura } \\
\text { dos pais ou responsáveis na folha } \\
\text { de transferência sem data, para o } \\
\text { caso de o aluno (a) não seguir as } \\
\text { determinaçóescdisciplinares da escola. } \\
\text { Este será transferido imediatamente; }\end{array}$ & Violência da Escola \\
\hline
\end{tabular}

Rev. Diálogo Educ., Curitiba, v. 9, n. 26, p. 161-179, jan./ abr. 2009 


\begin{tabular}{|c|c|c|}
\hline $\begin{array}{l}\text { d) Violência Verbal: } \\
\text { Incivilidades (pressão } \\
\text { psicológica) - humilhações, } \\
\text { palavras grosseiras, } \\
\text { desrespeito, intimidação } \\
\text { ou bullying. }\end{array}$ & 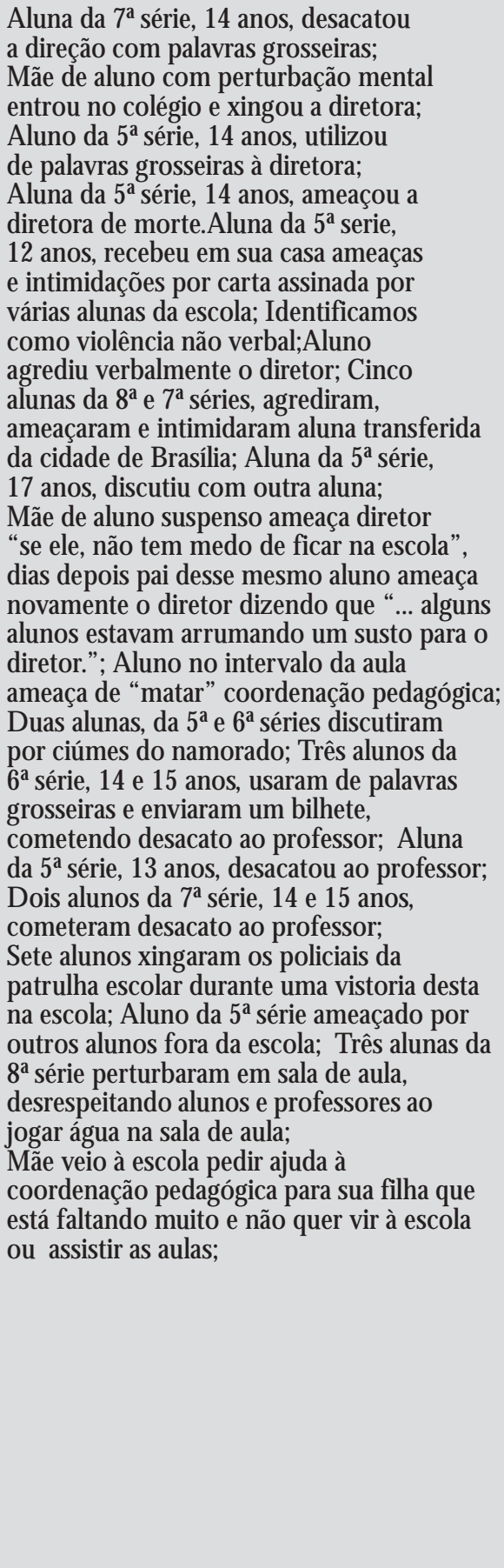 & $\begin{array}{l}\text { Violência na es- } \\
\text { cola: sefor cons- } \\
\text { tatado indícios } \\
\text { de Bullying, ou } \\
\text { Violência da es- } \\
\text { cola: se consta- } \\
\text { dado discri- } \\
\text { minação ou } \\
\text { práticas pedagó- } \\
\text { gicas que preju- } \\
\text { dicam a aluna } \\
\text { e/ ou caso esta } \\
\text { sinta-se } \\
\text { prejudicada. }\end{array}$ \\
\hline
\end{tabular}

Rev. D iálogo Educ., Curitiba, v. 9, n. 26, p. 161-179, jan./ abr. 2009 


\begin{tabular}{|c|c|c|}
\hline \multirow[t]{4}{*}{$\begin{array}{l}\text { e) Autores não fazem } \\
\text { descrição desse tipo } \\
\text { de violência das quais } \\
\text { classificamos como: } \\
\text { Atos de vandalismo, } \\
\text { roubo, incêndio, } \\
\text { destruição, depredação } \\
\text { com materiais, } \\
\text { equipamentos e área física } \\
\text { da escola. }\end{array}$} & $\begin{array}{l}\text { Primeiro livro ATA roubado no início } \\
\text { do ano letivo (2007); Alunos quebraram } \\
\text { vidro da porta da sala da direção; } \\
\text { Roubo na escola de torneiras do banheiro } \\
\text { masculino e feminino; Roubo na } \\
\text { escola de telhas externas, ralo do } \\
\text { bebedouro, fios elétricos, cabos de } \\
\text { telefones;Invasão no final de semana } \\
\text { na escola com roubo de } 2 \text { extintores } \\
\text { e lâmpadas; D ois alunos entraram } \\
\text { na despensa anexa à cozinha da escola e } \\
\text { roubaram comida;Roubo de telefone, } \\
\text { DVD da escola; Roubo de toda a fiação } \\
\text { elétrica da escola; Roubo de três pastas } \\
\text { de alunos da secretaria da escola; }\end{array}$ & $\begin{array}{l}\text { Violência } \\
\text { contra a escola }\end{array}$ \\
\hline & $\begin{array}{l}\text { Encontrada uma Arma de Fogo na sala } \\
\text { de aula da 5o série, uma pistola calibre } \\
45 \text { marca Auto no 93; }\end{array}$ & $\begin{array}{l}\text { Classificamos } \\
\text { como violência } \\
\text { contra a escola } \\
\text { pornão especifi- } \\
\text { ficar como por- } \\
\text { te de arma, } \\
\text { agressão física } \\
\text { e sem danos de } \\
\text { intimidação } \\
\text { à comunidade } \\
\text { escolar }\end{array}$ \\
\hline & $\begin{array}{l}\text { Aluno da } 6^{0} \text { série quebrou vidros das salas, e } \\
\text { tirou a massa dos vidros de outras janelas; }\end{array}$ & $\begin{array}{l}\text { Violência contra } \\
\text { a escola }\end{array}$ \\
\hline & $\begin{array}{l}\text { Carro do professor estacionado dentro da } \\
\text { escola foi riscado e teve dois pneus furados; } \\
\text { três alunos da } 70 \text { série estouraram uma } \\
\text { bomba caseira na porta da sala de aula; } \\
\text { do piso superior da escola; quatro alunos } \\
\text { do } 10 \text { ano do Ensino Médio de } 15-16 \text { anos } \\
\text { soltaram uma bomba no horário do intervalo; }\end{array}$ & $\begin{array}{l}\text { Violência } \\
\text { contra a escola } \\
\text { (aqui caracteriza } \\
\text { prejuízo para a } \\
\text { escola a partir } \\
\text { do momento } \\
\text {; que teve que } \\
\text { assumir o ônus } \\
\text { de pagar danos } \\
\text { no carro do } \\
\text { professor, } \\
\text { sendo também } \\
\text { uma violência } \\
\text { na escola vio- } \\
\text { lência contra a } \\
\text { escola- Atos de } \\
\text { vandalismo, } \\
\text { violência da } \\
\text { escola ao } \\
\text { expulsare } \\
\text { transferir } \\
\text { alunos. }\end{array}$ \\
\hline
\end{tabular}

Fonte: PRIOTTO, 2008, p. 97-103

Rev. Diálogo Educ., Curitiba, v. 9, n. 26, p. 161-179, jan./ abr. 2009 
Na sequência, apresenta-se as consequências geradoras de violência escolar identificadas na pesquisa Priotto (2008, p. 104-105) a partir dos três tipos de manifestações de violência escolar classificados como: violência na escola, violência contra a escola e violência da escola.

Violência na escola:

D esestruturação familiar: vem da família dos pais e depois ele traz isso prum colega e o colega admira; Parte da ineficiência da educação que o aluno recebe em casa. Pais separados.

Situação econômica, falta de comida na mesa, falta de trabalho; Eu to com duas famílias aqui que estão passando fome à criança chegou pra mim assim - olha nós não temos o que comer... e eu não sei nem se eu volto pra casa porque eu acho que eu vou sumir, porque sou mais um pra dar despesa para os meus pais. Eles não estão empregados e não temos o que comer. Pela situação dos alunos, da cultura deles, eles já trazem de casa, maneiras de agir que não soa próprias do ser humano que vá produzir coisas boas né,

A luno: tem revolta; ter poder; falta de perdão, religiosidade, amor, temor a D eus, respeito à vida, (noção de respeito), sem sentimento, sem emoção, afetividade, atira e mata porque não há amor; cumprimenta batendo, chama (o outro) xingando, falta de limite, não aceita mudar suas atitudes, perda da identidade, impõe medo, ameaçar, dar chutão, beliscão, bater e pegar na bunda das meninas, morder, bater boca. Ladrão, três assassinos condenados que merece uma chance que a gente dá, ladrão à vontade, ladrãzinho (são os alunos mesmos que roubam bicicleta, a vontade que são os alunos mesmos. Os alunos fazem assim tudo é marca qual a marca do tênis não tem marca - então é podre. 0 aluno que tem menos condições esse aluno se anula não pergunta encabulado ele nem levanta fica magoado pela situação isso é uma violência silenciosa. Violência tipo: te pego lá fora. Agressão física mais com a 5o série. Roubo de caderno; violência sexual; uso de entorpecentes, drogas, cigarro, À noite se não segurar com um pulso firme a gente perde a escola.

Relações profissionais: na relação de respeito de profissional com profissional, professor e funcionário (entra na sala de aula do outro professor abre a porta e entra, não bate, não pede licença, não chama pelo nome, não fala, por favor,

Rev. D iálogo Educ., Curitiba, v. 9, n. 26, p. 161-179, jan./ abr. 2009 
chama funcionário de "tio", ele o funcionário tem nome. E solas (professores) não suportam educar os filhos de pessoas que não colaboram de forma nenhuma com os educadores. (Pais) entrega o filho na escola - vire-se com esse problema. Fica difícil a escola passar conhecimento, educar para vida com objetivo bonito, muito difícil. Todos gritam senão não consegue dar aula.

V iolência contra a escola: Aluno chutar a porta, bater na porta. Vandalismo, ano passado prédio novo estragaram porta, estragaram um monte de coisa, fechadura, riscaram, tacaram pedra. Violência externa a comunidade veio roubar fio, quebraram vidro com pedrada.

\section{Violência da escola}

E soola como problema social: todas as relações que passam aqui na escola volto a dizer, a gente passa grande tempo junto, a gente extrapolou essa condição que é respeitosa. Escola não forma para 0 trabalho e nem para que 0 cidadão tenha consciência da realidade, Aluno chega totalmente despreparado na escola chega sem acompanhamento. (diretora) Existem os que acham que você está sendo boazinha porque quer se eleger sabe? Resultado é da falta de preparo da escola que na grande maioria das vezes não sabe lidar com o problema. E diante disso a escola não dispõe de meios para combater ou prevenir o crescimento da violência escolar Professor: a formação do professor, a formação de graduação teoria e prática, ou seja, com a vivência da teoria na prática é pouca mesmo. Professor se perde na orientação devido à enxurrada deinformações que o aluno tem acesso. Professor está bem amedrontado com as ameaças. Professor tirando aluno de sala. Mandar dentro da sala. Coloca a gente pra trabalhar (limpar caixa d'água). Existe certa intolerância por parte do professor em estar lidando com os alunos problemas. Professor não espera pra conversar já grita. E studo/ C onteúdo: falta significado que 0 aluno tem pelo estudo, se 0 aluno não ta entendendo o conteúdo ele se torna o sujeito que faz a violência escolar. Eles não encontram porque estudar. Aluno esta se sentindo coagido, pressionado e não sabe o que vai acontecer com ele, no sentido com aquela educação o que ele faz com aquilo então é uma forma de externar várias formas de violência. Aluno sem maturidade para entender;

Rev. Diálogo Educ., Curitiba, v. 9, n. 26, p. 161-179, jan./ abr. 2009 
Para que se possa compreender melhor a questão das definições classificadas pela pesquisadora (PRIOTTO, 2008), o depoimento a seguir demonstra um exemplo de Violência na escola e violência da escola: na fala do entrevistado, esta envolve tanto a violência na escola como da escola, sendo isso aceitável, pois se disse da importância de analisar os fatos, para então classificálos não sendo determinantes como únicos a uma classificação.

O Juiz manda muitas crianças $14-15$ anos com duas ou três passagens pelo CIAADI, são alunos de 14-15 anos sem fazer a 5 a série, quase nenhum vem se fumar maconha, sem estar traficando lá fora entra aqui dentro e nossos alunos, muitos não sabem nem falar palavrão. Aprendem são aliciados. Tem aliciamento de menores têm uma menina de 14 anos, aqui do ladinho do bar tem um bosquezinho e um barzinho abandonado ela com 4 crianças da 5 a série então 5 alunos meus, tinha três maços de cigarro com ela, primeiro ela acostuma com o cigarro e depois pega a maconha. Então que inclusão é essa e que exclusão nós estamos fazendo porque no momento que nós estamos incluindo os ruins, nós estamos excluindo os bons. (PRIOTTO, 2008, p. 114).

Portanto, a classificação apresentada na Tabela 1 e os depoimentos citados mostram que as entrevistas realizadas na pesquisa e aqui apresentadas indicam que a violência escolar tem origem em problemas que acometem o dia-adia da escola, muitos dos quais não podem ser resolvidos sem que se busque por soluções coletivamente. O u seja: faz-se necessário a presença e a participação efetiva de professores, funcionários, pais, alunos, direção e líderes da comunidade nas discussões acerca dos caminhos a serem traçados na solução destes problemas.

\section{CONCLUSÃO}

D entre as análises desenvolvidas neste texto, percebe-se que os conceitos de violência descrevem-na como um fenômeno essencialmente humano, construído histórica e culturalmente pelas civilizações, permeada em suas modulações, tanto por fatores psicológicos como sociais e culturais.

Assim, nas classificações apresentadas, a definição do termo violência escolar torna-se mais abrangente em relação das que normalmente são apresentadas em grande parte dos escritos so bre a questão, pelo fato de fazer uma diferenciação entre a violência na escola, a violência da escola e a Violência contra a escola. Isto é, constata-se que, a partir dos dados pesquisados por Priotto (2008), a violência

Rev. D iálogo Educ., Curitiba, v. 9, n. 26, p. 161-179, jan./ abr. 2009 
escolar surge de problemas que acometem o dia-a-dia da escola, e que muitos não podem ser resolvidos, sem que se busque por soluções coletivamente, ou seja: faz-se necessário a presença e a participação efetiva de professores, funcionários, pais e alunos, direção e líderes da comunidade nas discussões acerca dos caminhos a serem traçados na solução destes problemas.

Constata-se assim que a violência escolar apresenta formas e características diferenciadas à escola, agindo não apenas como vítima, mas também como produtora de violência. Mesmo assim observa-se que na fala dos entrevistados, através de pesquisa realizada por Priotto (2008), apenas uma minoria de professores admite que a escola produz violência, salientando que as causas que contribuem para o aumento da violência escolar são problemas que 0 aluno traz de casa. Para esses professores, a escola está para ensinar quem quer aprender, quem não quer, gera violência, e que a escola se constitui do local onde ocorrem as violências geradas por problemas familiares, por desestruturação familiar. Tal conclusão reduz, e exime, a escola e demais membros desta de qualquer responsabilidade sobre a produção de violência, o que contraria as evidências dos dados analisados ao longo deste texto.

Este texto não tem a pretensão de apresentar conclusões definitivas sobre a questão, mas, antes de tudo, apresentar questões novas para o debate sobre esta problemática que tanto angustia a sociedade brasileira como um todo.

\section{REFERENCIAS}

ABRAMOVAY, Mirian et al. E scola e violência. Brasília: Unesco, 2003. . (O rg.). Violência nas escolas: situação e perspectiva. Boletim 21, Unésco, v. 1, p. 3-12, 2005.

AD ORNO, Sergio. Crime, justiça penal e desigualdade judiciária: as mortes que se contam no tribunal de júri. Revista da USP, v. 21, p. 132-151, 1994.

AMO RIN, Cloves; RO MANELLI, Beatriz. A auto-estima e o Bullying: uma possibilidade de atuação do psicólogo escolar/ educacional. Psicologia Argumento, Curitiba, v. 4, n. 10, p. 63-69, 2005.

CALDEIRA, Suzana Nunes; REG O, Isabel E. Contributos da psicologia para 0 estudo da indisciplina na sala de aula. Estudos da Psicologia, Campinas, v. 18, n. 1, p. 76-96, 2001.

CAMACHO, Luiza Mitiko Y shiguro. As sutilezas das faces da violência nas práticas escolares de adolescentes. E ducação e Pesquisa, São Paulo, v. 27, n. 1, p. 123-140, 2001.

Rev. Diálogo Educ., Curitiba, v. 9, n. 26, p. 161-179, jan./ abr. 2009 
CHARLOT, Bernard; Ė MIN, Jellab, Aziz (Coord.). Violences à l'école: état des savoirs. Paris: Mason 7 Armand Colin, 1997.

. A violência na escola: como os sociólogos franceses abordam essa questão. Sociologias, Porto Alegre, ano 4, p. 432-442, 2002.

COLO MBIER, Claire. A violência na escola. Tradução de Roseana Kligerman Murrayl. São Paulo: Summus, 1989.

DEBARBIEUX, Eric. A violência na escola francesa: 30 anos de construção social do objeto (1967- 1997). E ducação e Pesquisa, São Paulo, v. 27, n. 1, p.163-193, 2001.

FUKUI, Lia. Estudo de caso de segurança nas escolas públicas estaduais de São Paulo. Cadernos de Pesquisa, n. 79, p. 68-76, 1991.

FURLONG. Michael. The school in school violence: definitions and facts, 2000. Boletim 21, Unesco, v. 1, p. 16-27, 2005.

LATERMAN, Ilana. Violência e incivilidades na escola. Florianópolis: Letras Contemporâneas, 2000.

PEREIRA, Maria Auxiliadora. Violência nas escolas: visão de professores do Ensino Fundamental sobre esta questão. 2003. Dissertação (Mestrado em Educação) - Escola de Enfermagem de Ribeirão Preto, Universidade de São Paulo, São Paulo, 2003. p. 114.

PRIOTTO, Elis Palma. Características da violência escolar envolvendo adolescentes. In: EDUCERE. Congresso de Educação da PUCPR, 6, 2006. Curitiba. Anais... Curitiba: Champagnat, 2006. p 16-28

. Violência escolar: políticas públicas e práticas educativas. 2008. $\overline{2} \overline{0} \overline{\mathrm{f}}$. D issertação (Mestrado em Educação) - Pontifícia Universidade Católica do Paraná, Curitiba, 2008.

SPÓ SITO, Marília Pontes. Um breve balanço da pesquisa sobre violência escolar no Brasil. Revista E ducação e Pesquisa, São Paulo, v. 27, n.1, p. 24-39, 2002.

Recebido: 10/ 05/ 2008 Received: 05/ 10/ 2008

Aprovado: 15/ 06/ 2008

A pproved: 06/ 15/ 2008

Rev. D iálogo Educ., Curitiba, v. 9, n. 26, p. 161-179, jan./ abr. 2009 